\title{
Preface: Ninety Years - Something Old and Something New
}

Mare Kõiva, Eva Toulouze, Nikolai Anisimov

The book you have in your hands is not an ordinary book. It is the first wider approach to Udmurt folklore in English. Udmurt folkloristics has a relatively long history: taking into account the general pattern of cultural development it is more than one and a half centuries. Unhappily for international communication, it is overwhelmingly in Russian. This is the first systematic attempt to open up this rich material to the international scholarly community.

To understand Udmurt folklore, it is relevant to start with general information. The Udmurt are one of the numerous indigenous peoples living in Russia, and the Udmurt Republic is part of the Russian Federation. Geographically, Udmurtia is in Central Russia, near the Ural Mountains and between the Rivers Kama and Vyatka, in the so-called Volga region. An important characteristic, that is highly relevant to Udmurt identity is that the Udmurt belong to the Finno-Ugric language family, which means that they feel incorporated with other communities into a wider ensemble, speaking languages from the same origin and thus feeling a kin connection. Today the Udmurt form only $28 \%$ of the population, 
within an industrial republic of 1.5 million inhabitants. The percentage of indigenous inhabitants has decreased continuously over the last decades (in 2010 there were 552,299 Udmurt in Russia, circa 100,000 less than in 2002). It is possible that one of the reasons is that the region's, but mainly the capital Izhevsk's, standard of living is one of the best among Russian cities (Census 2010) and so is undoubtedly attractive to others. We must add that the Udmurt do not live only in the eponym Republic: there are also significant groups of Udmurt living in the Republics of Tatarstan and Bashkortostan as well as in other nearby regions (Kirov and Perm' oblast', the Republic of Mari El, etc.). Apart from these core territories there are Udmurt in other regions as a result of migration: in Siberia, for example, but also abroad. At the same time, northern Udmurtia is home to an ethnic group whose culture deserves particular attention, i.e. the Besserman who live alongside the northern Udmurt. They share some aspects of their culture, while others are distinct. Their language is thoroughly connected to Udmurt, but has its peculiar features which have been deeply investigated in recent years. Ethnographer Elena Popova, herself from this group, has dedicated many works to Besserman culture, and here she proposes a study on their ritual culture and mythological world.

The authors of these current studies propose an insight about different domains of folk culture, such as mythical narratives (about heaven, the forest and water, the homestead), calendar as well as birth rites and the fading of relevant rituals, ethnomusicologic fields, the role of the individual Kulturträger, etc. Both in subject and methods contemporary approaches and new, interdisciplinary, results are emphasised. Indeed, in social sciences, the methods of different disciplines and their theoretical equipment differ, but they complete each other and their combination allows for richer outputs. 
The first Udmurt academic scientific institution, the Institute of Complex Scientific Research, was founded in 1931 in the Udmurt Autonomous Republic, which had been created roughly one decade before. It was a very important step for the scientific community, for it gave Udmurt the framework to investigate their own culture. The Institute was active not only in researching Udmurt history, language and folklore, but also in regional and kolkhoz economics, and in following the use of natural resources. In the organisation chart of the Institute, we do not explicitly find a folklore department, which is also lacking today: in Russia, folkloristics is traditionally encompassed within what is called philology, and therefore famous folklorists work in the philology department. Working in a common structure postulates cooperation with archaeologists, ethnographers, ethnomusicologists and linguists, and institutional continuity allows scholars to widen their approaches, in other words to integrate through historic and comparative discourse previously collected material in contemporary observation, not forgetting that research always takes place within the given political and social boundaries.

\section{Empire, religion, and revival}

These socio-political aspects are not to be ignored. The Udmurt are among those communities whose language bearers are not numerous and thus find themselves, as an ethnic minority, in a critical situation, as they were since the Russian Empire as well as in the following years within the Soviet Union. They have been integrated throughout history into an Empire, which has significantly influenced their culture and their ways. The Udmurt share the fate of other Finno-Ugric and other-language-speaking communities in that in the $16^{\text {th }}$ century their lands were included in what was becoming the Russian empire (in 1552, the capital 
of the Turkic khanate of Kazan was taken by Ivan the Terrible's army). In the $18^{\text {th }}$ century Udmurts and others in the region fled Evangelisation and poverty in whole groups to neighbouring areas (Toulouze, Anisimov 2021).

Thus, Udmurt religious history encompasses long contact with Christianity and Islam as well as a long period of religious conversion. From the point of view of our topic, we must take into account that until the end of the $19^{\text {th }}$ century some Udmurts, those who had not merged into the Russian language and culture, and had not totally accepted Christianity as their own, had maintained their syncretic and animist beliefs, sometimes even alongside Orthodox practice. Some went over to "the Tatar faith" (Sadikov 2019). The permanence of the previous religious practice disturbed the state authorities, for it showed that the Udmurt had not yet given their full allegiance to the tsarist regime. In the $19^{\text {th }}$ century, some religious movements attempted vainly to bring the Udmurt together (a movement called Vyle Pyris' 'those who enter above', or the 'lime tree worshippers', see Sergei Filatov and Aleksandr Shchipkov 1997: 177 ff.). But their protests never reached the level of the attempts by the Mari to have their right to their own worship restored (Lallukka, Popov 2009). Religious strife reached liberal-minded Europe with the Multan affair (1892-1896), in which Udmurt pagans were framed for performing human sacrifices in three widely publicised court cases. It was a time of religious intolerance all over Europe. In a tradition set by the murder of William of Norwich (the first accusation of ritual murder by Jews in 1144 (G. Bennett 2005)), several similar cases were known all over Europe by the end of the $19^{\text {th }}$ century, the best-known being the Dreyfus affair (1894-1906). This kind of case in Russia has been described by for example A. Panchenko (2000). A similar case of blood libel triggered anti-Jewish movements in Hungary (1882-1883). In all these cases, justice cleared the accused, as ultimately happened in the Multan case. The aim of this incident was to show that the 
Udmurt were still a savage pagan people and that enlightenment had to be forced into them.

In the following period, the religious question ceased to be as tense, for understandable reasons. With the revolution, Christianity was no longer a required standard. For some time, family and village rituals continued to take place in agrarian regions and the role of sacred places and sacred buildings (kuala for example) as sites of meeting and performing community rites remained unchanged. But the Udmurt, at that time as well as today, did not chose to institutionalise their religion. In this period, more elements of Christianity started to be integrated into their worldview: icons were put in sacred places and some Orthodox saints were merged with figures of Udmurt mythology (see Vladykin 1994: 213-216). The Udmurt were characterised by a powerful syncretism. Then came the time of collectivisation (1928-), which disrupted the Udmurt's agrarian community.

No people in the Soviet Union, big or small, could remain untouched by the economic changes and the repressions of the 1930s. The Udmurt intelligentsia was almost eliminated, ceremonial practice was discouraged, cult places in villages and families were destroyed or left to decay. The Udmurt were treated as if their own cultural expression was a threat to Soviet rule (Toulouze 2017). But the Udmurt were a small community, theirs was not an institutionalised religion, thus they were much more fragile than other well-known cultures and institutionalised religions. Nevertheless, these attempts to break the Udmurt and others' resistance did not succeed, their passive resistance turned out to be resilient enough.

This appeared clearly in the 1980s and the 1990s, another period that requires thorough observation. It was a time in which social, political and cultural movements emerged, aimed at highlighting Udmurt culture and at re-establishing the dignity of Udmurt history. Spiritual quest and continuation of old customs were and still are a relevant element of Udmurt identity and self-determination. 
Mare Kõiva, Eva Toulouze, Nikolai Anisimov

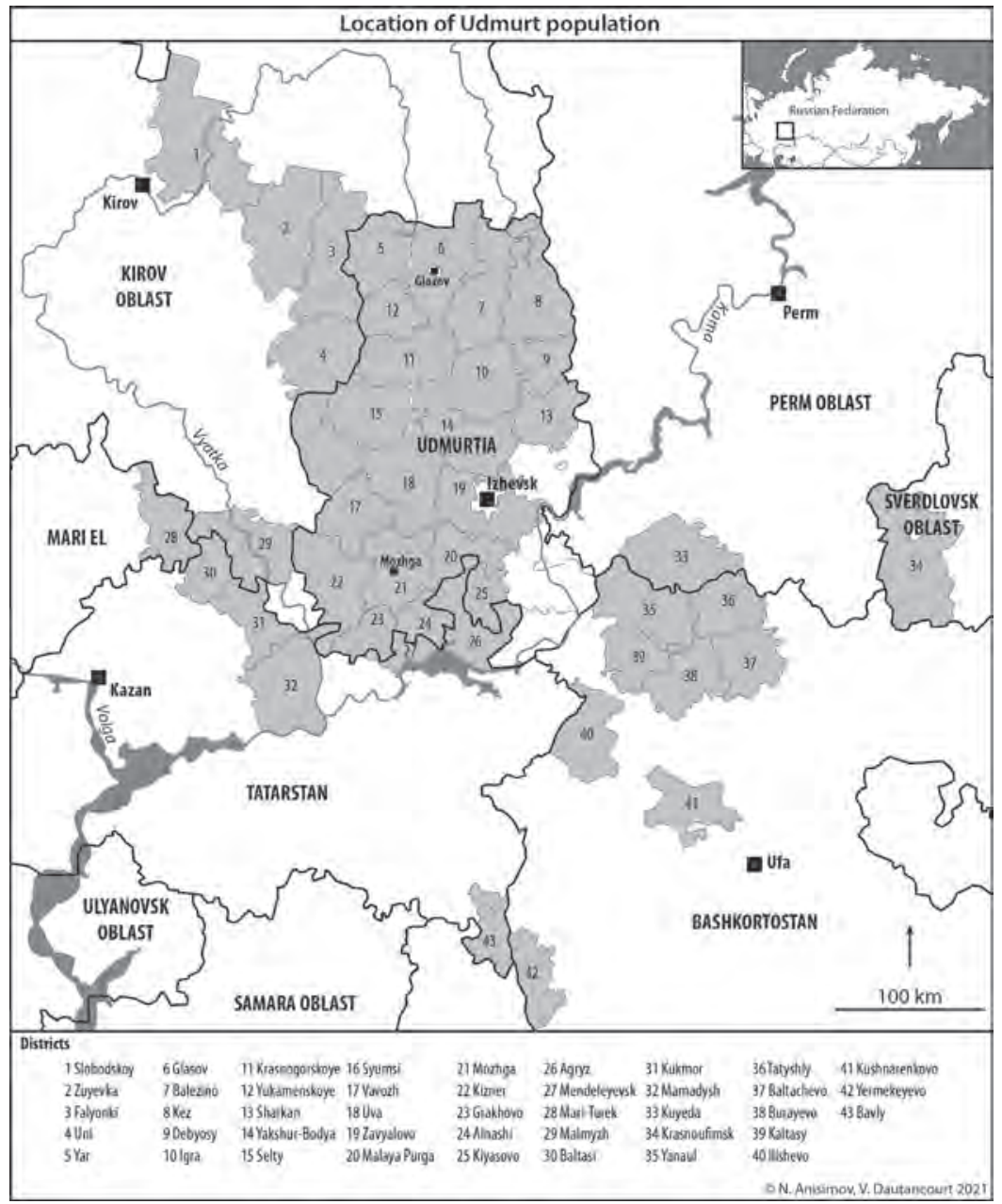

Map 1. Location of Udmurt population. 
The reflection on folk religion and religious narratives has been influenced in the last decades by the results of cognitive and neurosciences. In our context, it is important to take into account the fact that experiments and observations have rejected the idea that belief in the supernatural relies on intuitive thinking and that it is possible to reduce it by developing knowledge and analytic reflexion. Today, we would insist on social and cultural upbringing. This is the foundation on which religious thinking can emerge and resist, which means that its role is more significant than other factors (Farias et al. 2017).

Some important articles in our collection focus on religious practice and its context. Thus, Nadezhda Shutova, commenting on sacred ritual space, draws our attention to the reconstruction of "traditional sacral space (which) is being updated by the eastern Udmurt in Bashkortostan, in a dozen villages in Udmurtia and Tatarstan. Another ongoing project in several administrative regions is the formation of an Udmurt ethnic sacred landscape, with the annual republic celebrations, called Gerber in Udmurtia" (see p. 240). Eva Toulouze and Liivo Niglas reflect on the contemporary practice of Udmurt religion in Bashkortostan, one of the regions where this form of worship is the natural way for people to be themselves.

This process of revival is not an unknown phenomenon. While it is reminiscent of some aspects of European movements from the beginning of the $20^{\text {th }}$ century (Hann 2002; Chari, Verdery 2009), in which old customs were revived in the quest to find people's roots and traditions, the highlighting and revival of one's culture and religion found a new impetus in the 1990s. In the post-socialist space there have been similar movements in Mongolia and in Yakutia (Republic of Sakha). Is this a universal trend? The goal was not a pure return to the past, but a confirmation of one's identity, one's roots, through tradition, however inserted into the modern world. The peculiarity for the Udmurt and other northern Finno-Ugrians was that their communities 
had direct access to knowledge from people who had personal experience of the older world and, even more important, worldview.

\section{Centre and periphery, local culture}

It is complicated to live in a peripheral culture, for several reasons. The foundation of research institutions at the beginning of the $20^{\text {th }}$ century and the national awakening gave young Udmurt scholarship the basis for development in compliance with modern requirements and entrusted this scholarship with a huge working field. For decades, Udmurt scholars have efficiently taken over the challenge and covered the tasks they had to achieve, while endeavouring to be present in scientific dialogue within Russia's scientific debate, as well as in international forums and working groups. They were compelled by reality to do so not in their mother tongue, which is not accepted in their country as a scientific language, but in Russian, which requires a deep awareness of cultural translation. This awareness must be even higher when achieving translation of their reflections in another language, for example English. Some cultural features are deemed to remain underexpressed, for translation does not allow these features to be transmitted properly. As Tatiana Vladykina, Galina Glukhova and Tatiana Panina observe: "Terminological vocabulary is locally differentiated: the northern Udmurt had the influence of Russian folk and Orthodox calendars, while the southern Udmurt and the Udmurt of the enclaves in Tatarstan and Bashkortostan had the influence of Turkic cultural traditions. These local variations in the calendar give the opportunity to consider the peculiarities of its formation and development, and its importance in the general system of ethnic culture" (see p. 30).

These and other questions emerge in the contents of this collection. Some of the articles are centred on Udmurt mythology and 
the characters in it, others on rituals and ritual life and others on topical issues, such as soundscape and individuals in culture, the importance of witchcraft in Udmurt rural life.

\section{Mythology}

The roots of mythology go back to time immemorial, and regretfully no complete written source has been found. Mythology has been reconstructed relying on different sources from manuscripts and publication of modern times, using archaeological data and folklore recordings of legends, myths and beliefs. The Udmurt mythological pantheon is rich and has been subject to scientific discourse since the $19^{\text {th }}$ century, but its key texts and connected rituals were deeply analysed during the $20^{\text {th }}$ century. The Udmurt mythological worldview has been commented upon in numerous writings by Udmurt scholars Vladimir Vladykin and Tatiana Vladykina, and by Vladimir Napolskikh, just to mention the most relevant, but by no means only, scholars.

The deities connected to different spheres of the world-model, their activities, as well as the rituals dedicated to them, are here commented upon in eight articles. Some of the articles encompass both mythological characters and rituals, as this is the case with the periods around the solstices. The celebration of the winter solstice from January $7^{\text {th }}$ to $19^{\text {th }}$, about which Galina Glukhova writes in detail, is accompanied by mumming and masking, as well as by new year's communication with the spirits of the transition time who come to inhabit the human space from their underwater dwellings. The summer solstice is connected with the image of the Mother/Foremother Invozho, who descends at this time of year from heaven to earth and is received with significant festivals. Both Galina Glukhova and Aado Lintrop comment, from different points of view, on the same phenomenon: Glukhova describes the 
actions that take place in this period, while Lintrop, with a keen philological sensitivity, draws parallels with Komi tradition and sets the whole religious complex against a wider background.

The Heavenly area, its construction, constellations and its Gods are central in one of the articles by Tatiana Vladykina. The research concentrates on the supreme deities, including the creator God and female foremothers. Extending the scope of the heavenly God to literature, Aleksey Arzamazov investigates the figure of Inmar, the Udmurt God, in modern Udmurt literature at the turn of the $21^{\text {st }}$ century. His study analyses predominantly ethnic and futuristic poems by Petr Zakharov, Viktor Shibanov and Anastasiya Shumilova.

Elena Popova introduces the role of springs and rivers as mythology (with the master spirits of water), looking at the ritual practice connected with them as a metaphor for the traditional world model and as a connector to different parts of space, including sky and earth. Popova concentrates on Besserman material, although in this case Besserman material dialogues efficiently with northern Udmurt material, which, although in detail may differ, in essence answers to the same logic.

Another joint article by Tatiana Panina and Tatiana Vladykina provides a detailed description of the appearance of forest spirits, with their distinctive features and functions, and presents how beliefs about those mythological beings have evolved over the last centuries (and are still partly alive today). The paper investigates the best-known mythological beings living in the woods: n'ulesmurt ('forest man'), palesmurt (lit: 'half man'), and obyda ('forest woman').

Finally, an article by Tatiana Vladykina and Galina Glukhova investigates the familiar spirits of domesticated space the master of the house, the master of the bathhouse and the master of the cowshed. 


\section{Place, ritual and materiality}

Ritual is never disconnected from location. Nadezhda Shutova, who has dedicated long years to sacred landscapes in the VyatkaKama region, dedicates her article to sacred places. Research on landscape has emphasised the social and symbolic 'creation' of the space through everyday practice, for landscapes reflect history, which has meanings, values and strengths. (See for example Tilley 2006, which is close to the results of Shutova's investigations.) Shutova defines sacred space as a complicated natural, historical and cultural, religious and mythological set, and divides the places into family, patronymic, conditional clan, village, regional, tribal and territorial units. Her reconstruction emphasises that in the surroundings of each village community, there was a complete system of cult places and sites with different levels of significance.

Two other contemporary rituals are described in this collection. One of them in detail: the Seeing off a Recruit ritual for boys is the object of Valeriia Fedorova's article. This is a ritual that is still alive in Udmurtia, with some changes for although the period a boy spends in the army today is very short compared to historical experience, it is the first time he leaves his home for a long period in order to delve into the unknown. The interest of Fedorova's treatment is its musical dimension, for she neatly presents the songs sung within the ritual, with the tune and the lyrics, and comments on them, reminding us that songs are an integral part of ritual activity.

Yyr-pyd s'oton (the 'giving of head and legs' of a sacrificial animal) is a family ritual still performed in some places in Udmurtia some years after the death of one's parents. It is the last commemorative rite dedicated to real people, who henceforth become ancestors. Denis Kornilov describes a peculiar yyr-pyd s'oton held in 2020 in a southern Udmurt village in honour of the inhabitants of the neighbouring villages Bagrash-Bigra and Orlovo, who died during the Second World War. This ceremony took place in spite of COVID-19 restrictions and was an original combination 
of a commemorative, and at the same time another, ceremony. It was a unique performance 'invented' by local activists in a village where the tradition has been lost, in order to answer the population's spiritual needs.

If the first article about rituals concentrated on the different spaces dedicated to them, the starting point for the last, by Vladykina, Glukhova and Panina, is an object, a bundle of coloured thread called a chuk, which has in everyday and in ritual contexts polysemic contents, starting from apotropaic magic and folk medicine to passage, calendar or recruiting rites. This article echoes Fedorova's article, for chuk is of material importance in the seeing off of a young man to the army.

\section{Personal folklore and the role of the individual in folklore}

The dialogue between the collector and the tradition bearer, the consistency between his/her worldview and repertoire, is an old research issue developed in folkloristics since Mark Azadowski's famous investigation "Eine sibirische Märchenerzählerin” (1926). This direction was subsequently pursued in different countries, for example in Estonia by Richard Viidalepp (1938, 2004), who alongside his long monograph on great storytellers, analysed remarkable storytellers, their performances and styles (2004). Juha Pentikäinen's research of individual anthropology about Marina Takalo's religion (1971) and the series of publications in different languages about Finno-Ugric and Nordic wise men, witches, singers (Paulaharju 1929; Siikala 1990; Saarinen 2018; Kõiva 1990; etc.) have given the opportunity, through research focused on performers, to elaborate new theoretical positions. In these articles we find analyses of the remarkable intellectual contributions and cultural strategies of contemporary informants and traditional experts. Irina Pchelovodova and Nikolai Anisimov concentrate 
on the phenomenon represented by Ol'ga Solov'yova (1932-2018), called Dzhakapay. They analyse her repertoire, her improvisation ability and her personal songs, which represent a kind of personal, and at the same time collective, memoire in musical form, as well as her spontaneous translations, her partnership with folklorists and her manifold roles of go-between.

The next papers allows us to get acquainted with other types of sacral specialist such as the witches and priests who, through their performance, influence for good or for evil, the life of their village. Eva Toulouze and Liivo Niglas' text on Udmurt sacrificial priests focuses on the key figure in Udmurt ritual, the sacrificial priest, called vös'as'/kuris'kis'. The paper attempts to sketch a pattern of contemporary function-performance and transmission, following and analysing changes introduced in recent decades. On another topic, still focused on personalities, Nikolai Anisimov's research on contemporary witchcraft in the Udmurt village examines how wizards and witches are seen in today's Udmurt society, including the evolution in the village of their reception. Of course, for understandable ethical reasons, Anisimov is less focused on real personalities, but on narratives and stories, which show the great relevance of this topic for Udmurt life today.

\section{Soundscapes in ethnomusicology}

As we have already seen, music has popped in through ritual analysis (pp. 215 etc). Music, especially song, is an unavoidable dimension in Udmurt folk culture, which encompasses much more than entertainment or an accessory role in ritual, rather it covers the entire field of communication, as researchers have emphasised (Gerd 1926; Nurieva 2014). The description of soundscapes and of sound ecology is also, independently of its relevance for Udmurt folk culture, one of the rising trends in anthropology and opens new opportunities for research. Irina Nurieva starts her article 
by reflecting on the sounds of the Udmurt village and of its environment, such as the forest. Alongside the acoustic milieu and natural sounds (such as animal noises), the mechanical sounds that accompany work come with traditional music and singing and form the unique soundscape of the region. Nurieva explores the norms of behaviour regarding sound in the acoustic community in villages. Irina Pchelovodova turns to instrumental traditions and gives a complete description of the uz'ygumy, the Udmurt traditional flute: the process of manufacture of the instrument, the way of playing it and the repertoire. As previously mentioned, Dzhakapay's art also brings us deeply into the musical world, with all of its communicational dimensions.

\section{About this book}

In the Philology Department of the Udmurt Institute there are fourteen scholars who have taken on responsibility for investigating the very wide domain of Udmurt traditions and folklore from different points of view. They work on folk narratives, folk songs, and musical culture, which includes games and dances, beliefs and ethnically central rituals, proverbs, riddles and sayings. But not only these: they also work on folk medicine, omens and predictions, incantations and prayers. Although this list seems incredibly long, it is indeed covered by publications and defended theses. It is the soil from which this collection of articles has emerged. This issue of the journal SATOR has been prepared through cooperation between the Department of Folkloristics at the Estonian Literary Museum, and the Udmurt History, Language and Literature Institute at the Federal Research Centre of the Ural Branch of the Russian Academy of Sciences. It started with Tatiana Vladykina's idea of presenting Udmurt mythology in English; under the encouragement of editors Nikolai Anisimov, Eva Toulouze and Mare Kõiva 
it grew as an insight into Udmurt folklore with a wider scope, including new and exciting topics.

The list of the authors reflects our wish to show that contemporary folk culture research can be an open field, a domain of dialogue between cultural insiders and outsiders. While in some regions the question of who is authorised to investigate culture is ongoing, we are convinced that the richness of research results depends on it reflecting a multiplicity of points of view. Of course, most of the authors are renowned Udmurt researchers. We find among them beacons of the Udmurt humanities such as Tatiana Vladykina, a classic author in folkloristics and ethnology, to whom we are happy to gratefully dedicate this book. Our homage to Tatiana Vladykina is enriched by recensions of two crucial books she has published in recent years. Moreover, we have collected some texts from students and colleagues that allow the reader to understand why Vladykina is scientifically, as well as personally, the object of both respect and affection.

Other authors are famous researchers, such as Irina Nurieva, Nadezhda Shutova, Galina Glukhova, Elena Popova, Tatiana Panina, as well as representatives of a new generation such as Irina Pchelovodova, Valeriia Fedorova, Denis Kornilov and Nikolai Anisimov, the latter representing both Udmurt and Estonian scholarship. Their articles cannot but reflect the results of the work of the previous generations. Contemporary scholars can often reach further, and are able to generalise knowledge, when relying on material collected a century ago and enriching it with contemporary data. At the moment, Udmurt scholars have not adopted a unified rule about the orthography of folklore terminology (ritual, sacred places names, deities etc). They are still discussing it among themselves. In these conditions we have decided to accept the way each scholar chooses to write these terms.

Among the outsiders to Udmurt culture there are texts by researchers, fans and lovers of Udmurt culture, who all are dedicated 
to it. Here we have chosen Aado Lintrop's, as well as Liivo Niglas' and Eva Toulouze's articles (relying on tradition, we consider the latter in this collection as an Estonian scholar, although she also represents French Finno-Ugristics).

We have said that this is the first overview in English of Udmurt mythology and folk culture. Hopefully it will not be the last. We are living a time of restrictions: there are political, geographical, and cultural boundaries; COVID-19 added to the obstacles to free communication. Nevertheless, this book is proof that goodwill and the desire to share in mutual cooperation can overcome these obstacles, and we are ready to go further.

We are grateful to Daniel Edward Allen, who polished the English text, and to Diana Kahre, who was of great support at every step of the achievement of this book.

\section{References}

Azadowski, M. 1926. Eine sibirische Märchenerzählerin. FF Communications 68. Helsinki: Suomalainen Tiedeakatemia, Academia Scientiarum Fennica.

Bennett, G. 2005. Towards a Revaluation of the Legend of "Saint" William of Norwich and its Place in the Blood Libel Legend. Folklore, 116 (2), pp. 119-139.

Census 2010. Vserossiiskaya perepis naseleniya. http://www.gks.ru/ free_doc/new_site/perepis2010/croc/perepis_itogi1612.htm.

Chari, S., Verdery, K. 2009. Thinking between the Posts: Postcolonialism, Postsocialism, and Ethnography after the Cold War. In: Comparative Studies in Society and History 51(1), pp. 6-34. 0010-4175/09 \$15.00 \#2009 Society for the Comparative Study of Society and History. DOI: 10.1017/S0010417509000024.

Farias, M., van Mulukom, V., Kahane, G., Kreplin, U., Joyce, A., Soares, P., Oviedo, L., Hernu, M., Rokita, K., Savulescu, J., Möttönen, R. 2017. Supernatural Belief Is Not Modulated by Intuitive Thinking Style or Cognitive Inhibition. Nature. Scientific Report. www.nature.com/ scientificreports. 
Filatov, S., Shchipkov, A. 1997. Udmurtia: Orthodoxy, Paganism, Authority. In: Religion, State \& Society 25 (2), pp. 177-183.

Gerd, K. 1926. Votyak v suoikh pesnyakh. Glava 1. Pesni o pesnyakh [The Votyak in His Songs. Chapter 1. Song about Songs]. Votyaki [The Votyak]. Moscow, pp. 17-41.

Hann, C. 2002. Postsocialism: ideals, ideologies and practices in Eurasia. London: Routledge.

Kõiva, M. 1995. From Incantations to Rites. In: Kai Vassiljeva, Mare Kõiva (eds). Folk Belief Today. Tartu: Institute of Estonian Language and Estonian Literary Museum, pp. 215-236.

Lallukka, S., Popov, N. 2009. Testing the limits of the permissible. Mari ethno-religious ferment and Russian authority, 1820s-1840s. In: Michael Branch (ed.) Defining Self. Essays on emergent identities in Russia Seventeenth to Nineteenth Centuries, Studia Fennica, Ethnologica 10, pp. 316-333.

Nurieva, I. 2014. Udmurtskaya muzykal'no-pesennaya traditsiya; spetsifika zhanroobrazovaniya i funktsionirovaniya [The Udmurt Musical and Singing Tradition: Peculiarities of Genre Formation and Functioning]. $\mathrm{PhD}$ Dissertation. Izhevsk.

Panchenko, A. 2000. "Strange faith" and the blood libel. In: Fol'klor i postfol'klor: struktura, tipologiya, semiotika. Staraya Ladoga Collection. Vol. III. Saint-Petersburg: Staraya Ladoga.

Paulaharju, S. 1929. Vienan Karjalan tietäjistä. In: Kalevalaseuran vuosikirja 9. Helsinki: Suomalainen Kirjallisuudern Seura, pp. 177-184.

Pentikäinen, J. 1971. Marina Takalon uskonto: Uskontoantropologinen tutkimus. Suomalaisen Kirjallisuuden Seuran toimituksia 29. Helsinki: Finnish Literary Society.

Saarinen, J. 2018. Runolaulun poetiikka: Säe, syntaksi ja parallelismi Arhippa Perttusen runoissa [Poetics of Runic Songs: Song, Syntax and Parallelism in Arhippa Perttunen's Songs]. PhD Dissertation. Helsinki: University of Helsinki.

Sadikov, R. 2019. "Prezhde zhe khotya i byli yaztchniki, no nyne magometanskogo veroispovedeniya": $\mathrm{k}$ voprosu o prinyatie islama zakamskimi udmurtami [Formerly, We Were Pagans, but Now We Follow the Faith of Islam]. In: Voprosy vostokovedeniya [Questions of Oriental Studies] 2 (84), pp. 32-37. 
Siikala, A.-L. 1990. Singing of Incantations in Nordic Tradition. In: Tore Ahlbäck (ed.) Old Norse and Finnish religions and cultic place-names. Helsinki: Almqvist \& Wiksell International, pp. 191-205.

Tilley, C. 2006. Introduction: Identity, Place, Landscape and Heritage In: Journal of Material Culture, Vol. 1 (1-2), pp. 7-32. DOI: 10.1177/1359183506062990.

Toulouze, E. 2017. A long terror in the Volga region: a war before the war. In: A. Kotljarchuk, O. Sundström (eds.) Ethnic and Religious Minorities in Stalin's Soviet Union: New Dimensions of Research. Södertörn Academic Studies 72. Huddinge: Södertörn University, pp. 153-172.

Toulouze, E., Anisimov, N. 2020. An ethno-cultural portrait of a diaspora in central Russia: the formation and culture of the eastern Udmurt. Folklore: Electronic Journal of Folklore 79, pp. 31-58. DOI: 10.7592/ FEJF2020.79.toulouze_anisimov.

Viidalepp, R. Ühest suurjutustajast ja tema toodangust [About a Great Narrator and His Production]. In: Õpetatud Eesti Seltsi toimetused XXX. Tartu: K. Mattiesen, pp. 830-845.

Viidalepp, R. 2004. Eesti rahvajuttude laadist, funktsioonist ja jutustajatest [About the Nature, Function and Narrators of Estonian Folk Tales]. Reet Hiiemäe (ed) SATOR: Artikleid usundi-ja kombeloost Tartu : Eesti Kirjandusmuuseum.

Vladykin, V. 1994 Religiozno-mifologicheskaya kartina mira udmurtov [Religious and mythologic worldview by the Udmurt]. Izhevsk: Udmurtia.

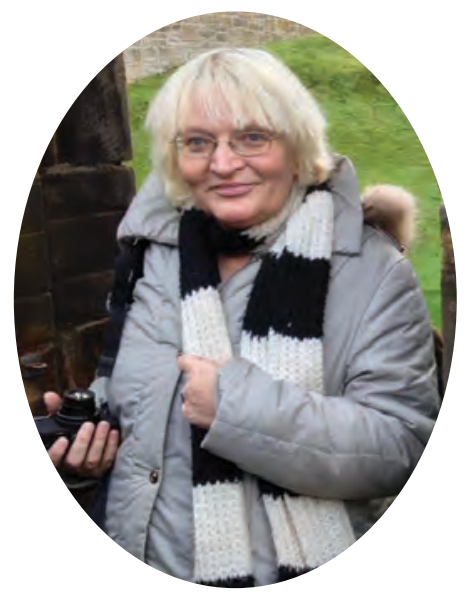

Mare Kõiva $(\mathrm{PhD})$ is Head of the Centre of Excellence in Estonian Studies, and Leading Research Fellow, Head of the Department of Folkloristics at the Estonian Literary Museum, Estonia. Her main research areas are charms and charmers, belief narratives, mythology, and human/non-human relationships. e-mail: mare.koiva@folklore.ee 


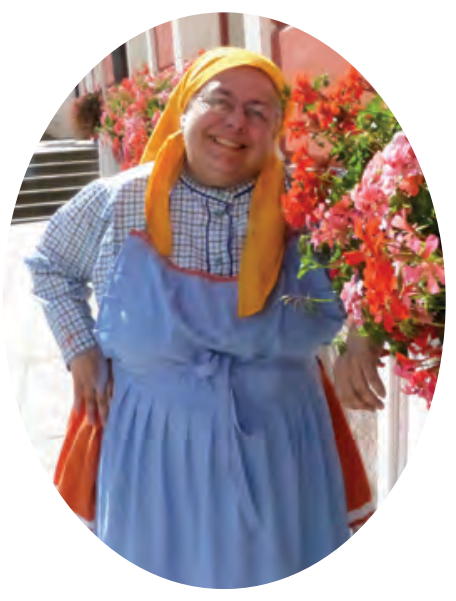

Eva Toulouze ( $\mathrm{PhD}$ hab) is a professor of Finno-Ugric languages at the Institute of Eastern Languages and Cultures (INALCO, Paris), and a researcher at the Department of Ethnology, University of Tartu, Estonia. Her main fields of interest are the cultures of Russia's FinnoUgric peoples, the emergence of a written culture in Finno-Ugric areas, Forest Nenets culture and Udmurt religious practice.

e-mail: evatoulouze@gmail.com

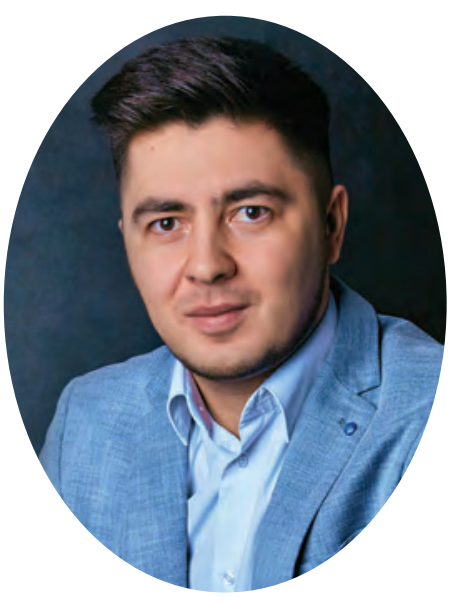

Nikolai Anisimov ( $\mathrm{PhD}$ ) is a researcher at the Department of Folkloristics at the Estonian Literary Museum, Estonia, and at the Department of Philological Studies at the Udmurt Institute for Research in History, Language and Literature (Udmurt Federal Research Centre of the Ural Branch of the Russian Academy of Sciences). His main field of interest is Udmurt traditional and contemporary culture, and more precisely, the Udmurt living ancestors' cult, and their singing tradition.

e-mail: nikolai.anisimov@folklore.ee 